\title{
Cinqüentenário de Um Texto à Luz do Tempo*
}

\author{
Régis Duprat
}

"Panorama de la Música Hispanoamericana (esbozo interpretativo)", de Otto Mayer Serra, conhecido musicólogo mexicano e historiador da música, foi escrito em 1942 e publicado em 1950, na Enciclopédia de Música Atlante, no México. O texto foi republicado em uma coletânea chamada Musicologia en Latinoamerica, Ed. Arte y Literatura, Havana, Cuba, 1985, p. 56-91 (35 p.) e organizada por Zoila Gomez Garcia. Nosso objetivo, aqui, é proceder a uma despretensiosíssima interpretação de um texto que comemora 50 anos da primeira divulgação, e encará-lo à luz dessa trajetória de meio século que viveu.

Dado que não constitua um texto amplamente conhecido por todos, é claro que devo contar com um crédito de confiança de meus leitores para o pressuposto de minha fidelidade a ele. É mais do que confiança; é um texto que fica proposto como resultado de uma reflexão sobre aquele que serviu de base para isto: $o$ arquitexto, se assim podemos falar, que, na realidade, não ficará reconhecido aqui. Mas isso não importa. Assim me pareceu que deveria proceder, por convencer-me de que toda leitura é sempre e inapelavelmente a interpretação hermenêutica de um texto.

$\mathrm{O}$ A. divide o trabalho em quatro segmentos, cuja ordem questionei, por não sintonizar com a sua concepção evolucionistapositivista da história musical:

* Conferência no Curso de Difusão Cultural "América 92: Pluralidades". ECA/USP, set. 1992. 
1. Presença ante o mundo musical;

2. Crescimento da cultura musical hispanoamericana;

3. Prática musical indígena;

4. A conquista e a época colonial.

É como se o A. se dispusesse a partir de uma crítica do não-reconhecimento internacional da música hispanoamericana, para mostrar como ela cresceu, e depois abordar as premissas desse crescimento. Na minha interpretação, proponho uma nova ordem do discurso:

1. Prática musical indigena;

2. A conquista;

3. Crescimento;

4. Presença ante o mundo (europeu).

E o faço por considerar a ordem original um artifício subliminar para não denunciar a sua concepção histórico-positivista, resumida nas etapas necessárias de uma evolução previamente estabelecida na interpretação que o A. faz da realidade do seu Panorama. Qual seja: no princípio era a América, com suas práticas musicais indígenas. Veio o descobrimento e, com ele, a conquista; e esta envolveu o simples traslado de uma prática musical européia, tanto culta como popular. Há indícios, no texto do A., de que a música culta predominaria sobre a popular. Esta se configuraria à base de influências e da assimilação daquela. É claro que esse mecanismo permaneceu social e musicalmente inexplicado, mas é uma postura. Assim, alguns problemas se colocam: 1. Quais as relações entre a música popular trasladada e a música dos indígenas? 2. A música dos indígenas não conhecia essa dicotomia música culta $\mathrm{x}$ música popular! O destino dela foi juntar-se às músicas populares trasladadas de Europa? Entre os colonizadores, a música culta era, grosso modo, a das classes abastadas e a popular, a do povo (dos pobres). No confronto da conquista, a música do conquistador transforma-se na música dos donos do 
mundo. A música do autóctone vai reforçar o caudal da música popular, a do povo. E durante o periodo colonial essa música popular ágrafa é eliminada sumariamente da tradição culta e oficial.

Mas diríamos que a música culta, grafada, também foi eliminada da tradição culta, recuperada apenas a partir de 50 anos atrás. $\mathrm{E}$, nesse mesmo período, as músicas populares também vêm sendo recuperadas. Não as do período colonial, é claro, por ágrafas, mas as do século XIX em diante.

\section{Prática musical indígena}

Para o A., são três as fontes possíveis de conhecimento da música dos povos ameríndios: 1) as fontes primárias do colonizador e os textos dos cronistas e viajantes do passado; 2) os testemunhos arqueológicos de instrumentos musicais (incluiríamos, também, aqui, os testemunhos iconográficos em geral, independentemente dos instrumentos musicais, a representação das danças, por exemplo); 3) as pesquisas das sobrevivências atuais.

As três fontes são por ele consideradas insuficientes para nos fornecerem elementos relevantes de conhecimento em profundidade, da prática musical dos povos pré-colombianos. Entretanto, o estudo comparativo entre diversas culturas americanas e delas com as de outros continentes poderia, segundo Mayer Serra, elucidar muitos problemas de difícil abordagem sobre essa música.

Sua concepção dos estados de evolução daqueląs culturas é positivista e pré-estruturalista, já que escrevia no princípio da década de 1940. Para ele, portanto, os povos indígenas americanos encontravam-se em estágios diversos de evolução, desde os "mais primitivos", com uma economia baseada na caça, na pesca e na coleta de produtos naturais, até os de nível adiantado de organização estatal, política e cultural; e outros em que já se manifestavam nítidas indicações de terem entrado na fase de desagragação. A ele não choca sequer, como à moderna antropologia, utilizar-se desembaraçadamente e com natural freqüência, da expressão "primitivo" para aqueles povos de cultura mais simples e singela. 
Para todas essas culturas, a documentação da citada natureza atesta que a música desempenhava generalizadamente um papel importante, sendo ostensiva a sua estreita função social e mágica. Cantos e danças ocupam espaço permanente na vida social desses povos e têm características monódicas, ainda que diversificadas, $\mathrm{e}$ acompanhadas sempre de instrumentos percutidos, e, os mais "evoluídos", de instrumentos de sopro e até com práticas antifonais.

A sua grande fonte para a classificação dos instrumentos musicais indígenas é a obra de Curt Sachs, História dos Instrumentos Musicais, então recém-publicada em Nova Iorque, em 1940. Assim, dele colhe a classificação hoje tomada com reserva, que identifica um estágio primitivo na música dos indigenas centroamericanos que não disporiam de instrumentos de cordas nem de sopro, exceto uma flauta simplíssima que permitiria executar apenas elementares melodias; os demais instrumentos seriam zunidores e percussores, provavelmente influenciados por modelos chineses pré-históricos (?). A par destes, os sistemas sul-americanos pretensamente mais evoluídos, com flautas e flautas de Pan de tubos múltiplos, sistemas de influência supostamente asiática (da Índia, Birmânia, Ilhas Malaias e Pacífico Sul). A bibliografia da Música Folclórica Latino-Americana, publicada em Washington em 1942, obra então recentíssima, constitui a sua base de informações para tais considerações.

Em questões classificatórias da disciplina, Mayer Serra se prende à denominação de "musicologia comparada" já utilizada por Adler, em 1913, e pelos europeus Robert Lach, Lachmann e Hornbostel, e hoje conservada teimosamente pela corrente alemã, em contraposição à denominação de "etnomusicologia", consagrada nos Estados Unidos e países de língua latina, expressão utilizada pela primeira vez em 1950 pelo holandês Jaap Kunst.

Quanto aos métodos de pesquisa sobre a música sobrevivente entre os indígenas atuais, o A. prognostica a utilização da gravação, procedimento científico por excelência na etnomusicologia, ainda que deixe transparecer a necessidade imperiosa de se publicarem 
as transcrições (evidentemente em notação inevitavelmente europeizante) dos arquivos de fonogramas, técnica hoje vista pela etnomusicologia com prudentes reservas; chega a citar, inclusive, uma obra posteriormente muito questionada, a Música dos Incas, dos D'Harcourt, de 1925, que procedeu a harmonizações de melodias indígenas, hoje coisa intolerável.

Outra questão de método que o A. coloca é a tendència então generalizada entre os etnomusicólogos ${ }^{1}$ de promoverem a tentativa de sistematização em escalas básicas utilizadas, ou interpretação harmônica da escala pentatônica, quando a tendência moderna, então, era a visão comparativa e o interesse pelas características fonéticas e expressivas do canto e pela classificação segundo os tipos melódicos.

\section{A conquista da época colonial}

Mayer Serra é consciente da lamentável necessidade de os colonizadores destruírem os templos pagãos, substituindo as práticas litúrgicas indígenas pelas cristãs. As citações escolhidas dizem sutilmente da interpretação hoje odiosa do cronista colonial em que as cerimônias religiosas aborígenes eram vistas como "gritos dos bailes, cantorias e bebedeiras". O mesmo cronista ${ }^{2}$ procura demonstrar que as festas divinas indígenas primavam pelos sacrifícios humanos e, por isso, eram hediondas e feias; já as cristãs eram puras, saudáveis e belas.

Quanto à liturgia musical a ser implantada no Novo Mundo, esta já estaria, à época dos descobrimentos, rigidamente codificada e integrada na consciência evangelizadora de colonizadores e missionários. Isto impedia qualquer possibilidade de absorção de elementos musicais locais que seriam, aliás, "procedentes de uma cultura de desenvolvimento inferior". Na Idade Média, a consagração do cantochão teria ocorrido na Europa, segundo P. H. Lang, ao preço da assimilação de práticas musicais autóctones, que teriam suscitado e fornecido os elementos da consolidação gregoriana. 
É claro que o aprendizado da música passa pelas práticas artesanais de fabricação de instrumentos, começando pelos sinos, para alcançar os órgãos e outros mais; e como base da liturgia, o aprendizado do canto, com cujos salmos, antífonas e hinos integravam-se os meninos índios na educação cristã. O A. cita, aliás, um documento da História da Música Brasileira, de Vicente Cernicchiaro (Milão, 1926), referindo-se à prática portuguesa de migrar meninos cantores órfãos de Lisboa, para promover a aproximação com os meninos índios e facilitar sua conversão pela prática da música.

A importação de livros de música provindos de Sevilha para a Guatemala, já começara no primeiro século da colonização. Aliás, dos primeiros anos (1512), também da Guatemala, datam as primeiras nomeações para funções de chantre e organista na igreja principal de Santo Domingo. Em Cuba, nesse mesmo século, também se nota a presença de instrumentistas para o culto, assim como para a música popular e militar. Já no século seguinte, o XVII, surgem as proibições de suas danças e músicas, mas incentivam-se as músicas sacras e profanas faustosamente descritas como festas barrocas de extremo requinte de luminárias, fogos de artifício, carros de máscaras e arcos triunfais, corridas de touros e representações de comédias.

As preocupaçōes com a evangelização levaram os colonizadores a mesclar entremezes, villancicos e trechos de bailes e cantos nas comédias pastoris. Essa é uma tradição peninsular ibérica. Uma das mais antigas manifestações é de 1535, no pastorcillo de Mateo Flecha, el Viejo, integrando a música negra africana e que Mayer Serra parece não ter conhecido. Já o pastorcillo citado pelo A. é de 1574 e se intitula "Desposorio espiritual entre el pastor Pedro y la Iglesia mexicana". Diz o seu texto:

Toca tu rabel, pastora

Que me fino de pracer

Todos bailen en buena hora

Que quien tiene senso agora 
No debe mucho temer

No quede ningun pasror

Que no baile com primor

$Y$ dé cién mil zapatetas

Yo daré mil castañetas

$Y$ salros en derredor.

A literatura histórica conhecida há 50 anos já permitia a Mayer Serra avaliar a quantidade imensa de documentos coloniais por pesquisar, recopilar e transcrever, e da necessidade de se desenvolverem pesquisas para conhecer o repertório musical europeu que era executado e que certamente, segundo ele, teria influído sobre a formação do folclore americano.

Mas, afora as pesquisas que àquela altura vinham sendo desenvolvidas por Juan Bautista Plaza na Venezuela, nas quais se descortinava a atividade do padre Pedro Sojo, falecido em 1799, e de uma segunda geração em que se destacou a figura de José Angel Lamas e Cayetano Carreño (1766-1836), Mayer Serra não acreditava, dada a precariedade das pesquisas ainda não implementadas no continente, na possibilidade dessas investigações virem a revelar "qualquer gênio ignorado da polifonia americana". Sua explicação, hoje improcedente, era de que este (s) gênio (s) se teria feito conhecer através de outros documentos, cuja natureza não declara. Condicionado pelas descobertas de acervos de composições de autores menores espanhóis e italianos, julgara que o período colonial era muito mais a época de predominância da assimilação pura e simples de estilos importados do que a de criação de valores novos. Assim, nenhuma referência sobre Juan de Araujo, Hernando Franco, Juan de Llamas, José Maurício, Lobo de Mesquita ou André da Silva Gomes. Preocupava-o, porém, a comprovação por comparação das descobertas polifônicas de Plaza, com a canção popular, sob a hipótese alimentada de que ali estivesse a origem da formação do nacionalismo musical hispano-americano. 


\section{Crescimento da cultura musical hispano-americana}

Em um dos segmentos do seu trabalho, Mayer Serra dá fecho com as seguintes palavras: "Como a evolução biológica, a musical caminha do simples para o complexo, do acidental para o conscientemente essencial, do particular para o geral". Segundo o autor, as obras mais representativas da produção musical hispano-americana pertenceriam à tendència nacionalista, para ele, único caminho viável. Não se trataria de um nacionalismo extremista, auto-suficiente, em que o patrimônio artístico do continente se bastasse a si próprio para gerar uma música claramente americana. Pelo contrário, a evolução - e Mayer Serra fala em "crescimento da música" - ocorreria em cada uma das fases evolutivas em função de uma sucessão de "hegemonias nacionais". Para o A., essas hegemonias ocorreriam sempre que um estilo ou escola nacional atingisse um determinado grau de sublimação e cristalização (?), absorvendo e fundindo as mais variadas correntes musicais de uma época, a ponto de tal estilo representar o limite superior (?) da prática musical. Assim sempre ocorreu no passado; e na atualidade (1940), mais do que nunca a rapidez das comunicações faz repercutir em todos os cantos do mundo os acontecimentos. Aí, "um isolamento nacionalista ofereceria os mesmos males que um universalismo nivelador".

Como exemplo, o A. cita os nacionalismos românticos russo, espanhol e húngaro, que culminaram nas figuras de Stravinski, De Falla e Bartók, cuja repercussão internacional se deveu à universalização dos materiais populares que aqueles nacionalismos integraram com as técnicas musicais mais avançadas. Nota-se aqui a presença de uma interpretação nitidamente característica da sua época e que se tornou pilastra da argumentação zdanoviana na década seguinte, de 1950, ou seja, de que bastaria ao compositor integrar os "materiais populares" com as técnicas (composicionais) mais avançadas, para compor música nacional e moderna.

Para Mayer Serra, os nacionalismos hispano-americanos seguem aqueles autores com 50 anos de atraso, numa tentativa de 
cumprir também uma "emancipação gradual" que iria da "citação folclórica textual" até a assimilação sucessiva das diferentes técnicas universais, único caminho para que a música hispano-americana atingisse o nível internacional, com contribuições de caráter nacional que transcendessem o cunho regional.

Mas como se formaria, para o nosso autor, essa corrente nacionalista? Ele não atribui tanta criatividade ao povo, como seria de esperar numa ideologia nacionalista; ao povo, cuja mística não lhe é das mais fortes. Citanto Bela Bartók (Música Popular Húngara, Oxford, 1931) e Carlos Vegas (Danças e Canções Argentinas, Buenos Aires, 1936), o A. lembra que as pesquisas do primeiro nos mostram que "o povo não inventa nada de suas canções. Limita-se a recolher, assimilar, transformar e conservar certos elementos da música culta através dos séculos". E como na América a música culta sempre foi importada até recentemente (?), não deve surpreender que as nossas músicas populares sejam carentes de qualquer sistema harmônico, estruturação formal, ou tipo melódico próprios, extra-europeus.

Se assim é, então como poderíamos explicar as inegáveis características nacionais de cada cancioneiro nacional americano, seja argentino, mexicano ou qualquer outro? Baseado no segundo autor, Carlos Vega, Mayer Serra explica simplesmente que as coisas se passam por seleção e assimilação de determinados elementos da música culta (importada) que se somam ao transplante ("integral ou parcial, textual ou modificado") de elementos populares peninsulares (também importados, portanto), que acabaram se consubstanciando, se cristalizando em estilos definidamente nacionais. Citando Carlos Vega, diz que o "caráter" (nacional) é o efeito que produz a freqüentação de idênticas fórmulas melódicas, rítmicas e harmônicas". Isto ocorreria, como diz Bartók, por um processo de homogeneização de procedimentos: após uma fase de coexistência de variantes melódicas de origem distinta, produzemse "melodias com traços comuns que conduzem a um estilo musical homogêneo". Nota-se aqui uma sintonia entre Bartók, Vega e 
Mayer Serra com relação à teoria da homogeneidade crescente na configuração das características de um estilo musical.

\section{Presença ante o mundo musical}

O segmento do artigo em que o A. aborda a presença da música hispano-americana ante o mundo musical, está impregnado de preocupação por explicar a tardia integração da música hispano-americana na historiografia musical universal. Logo de início, procura uma justificativa desse retardo na ininterrupta situação periférica do continente, caracterizada pela assimilação e absorção de bens culturais alienígenas, ou seja, europeus. A nossa cultura musical não teria repercutido decisivamente na vida européia como ocorreu com a vida econômica, política ou religiosa. $\mathrm{O}$ primeiro século da colonização assim permaneceu e as coisas começariam a reverter, segundo a sua visão, no século XVII, quando, junto com os ricos produtos coloniais, ganham Espanha algumas formas de música, especialmente as afro-americanas. Algumas teorias apoteóticas desabrocham assim, no texto, como por exemplo aquela de princípios do século XVII, de Giambatista Marino, tentanto estabelecer a origem americana, de Nueva España, da sarabanda e da chacona. $O$ certo é que a predominância dessa presença americana na Europa, dentre as citadas pelo A., é sempre afro-americana e nenhuma precede ao exemplo citado, do "pastorcillo", de Mateo Flecha, de 1535, que expressa a direta convivencia de escravos negros africanos na própria Espanha e que Mayer Serra parece não ter conhecido.

Outra tergiversação pouco convincente e muito discutível, atém-se a determinadas formas e ritmos espanhóis, que retornam à Espanha após uma incorporação prévia à nossa música hispanoamericana. É o caso da guajira cubana, incorporada hoje ao repertório dos cantaores flamencos de Espanha. E é o caso do ritmo binário e ternário combinados nos compassos $6 / 8$ e 3/4, características da siguiriya gitana e corrente no cancioneiro hispano-americano e que Torper, nas Danças Valencianas, identifica num 
cantarcillo do século XV, em várias sarabandas do século XVII e nas canções borgonhesas do século XV.

Para nós soa hoje, talvez, fortemente duvidosa a preocupação por identificar as etapas da projeção internacional da produção musical americana. Parece uma continuidade da citada e interminável absorção e assimilação de padrões europeus, agora em termos de busca de aprovação e reconhecimento... Assim o A. arrola os feitos novecentistas americanos no campo da arte lírica, a ópera de Carlos Gomes e do mexicano Melesio Morales e do violinista negro cubano José White, primeiro prêmio, em 1856, do Conservatório de Paris. Arrola ainda os êxitos europeus das danças americanas nos bailes de sociedade. É o caso, no início deste século, do maxixe, do tango, e depois da rumba e da conga, e, no século XIX, em 1860, o êxito das canções de salão, o da habanera "La Paloma", do compositor espanhol Sebastian de Yradier, de argumento mexicano e que precedeu a não menos famosa habanera "Tu", de Eduardo Sanchez de Fuentes, de 1890. Arrola, ainda, Mayer Serra os êxitos na música de concerto, com Villa-Lobos e Manuel Ponce, na década de 1920, e de Carlos Chavez, nos Estados Unidos e na Espanha, e do próprio Villa nos Estados Unidos.

Segundo o A., após 1925 a América está madura, com sua linguagem nacionalizada e, daí em diante, passa a ter direito de cidadania universal com a definição nítida de sua personalidade, a qual resultaria simplesmente de um processo evolutivo longo e difícil, intimamente ligado ao desenvolvimento dos nacionalismos. Isto nos parece hoje uma incrivel falácia... Tanto o problema do nacionalismo como o das músicas populares parecem passar pelo confinamento étnico e estético.

O confinamente estético é a expressão do confinamento étnico. Ele dura todo o período colonial. Sempre que ele é transgredido, é na base da citação do outro no espaço de quem cita. O confinamento é o branco na casa grande e no salão, o negro na senzala e o índio na aldeia, confinada ou não. O confinamento é espácio-cultural. É preciso um pretexto para haver uma citação. Para o branco, no caso de Mateo Flecha, por exemplo, esse pretexto é a universa- 
lidade da devoção: até os negros se dobram à homenagem ao menino Deus. Pois não havia entre os próprios Reis Magos um que era negro? Estes, então, participarão com seu idioma, seus ritmos e seus instrumentos, com sua música, da homenagem do Auto de Natal. Mas tudo é construído e fabricado pela imaginação do branco em função de um ecumenismo impositivo e parcial. Mas rompe-se, assim, o confinamento estético, forma inicial e paradigmática de rompimento de todo e qualquer confinamento étnico. $\mathrm{O}$ negro torna-se presente no salão de forma estética, ou seja, sensível (aisthesein). É um prenúncio, é um libelo abolicionista. Essa dialética convivência $\mathrm{x}$ confinamento perdurará até as Repúblicas e precisa ser melhor estudada.

$\mathrm{Na}$ América Espanhola o índio substitui o negro. Como? O índio é o dono da terra. O branco é o invasor. Mas este é tecnologicamente mais sofisticado e impõe um padrão de relação com a natureza. Nessa imposição ( $\mathrm{Ge}$-Stell, de Heidegger), o branco necessita integrar o índio, mas numa integração exclusivamente econômica. Ora, essa exclusividade constitui e logo se evidencia como uma utopia. É preciso também integrá-lo culturalmente, no que o branco enfrenta grandes dificuldades, por possuir tecnologia avançada apenas no trato com a natureza, mas não no trato com as ciências humanas. A sociologia só surge no século XIX. O próprio conceito de integração deve ser revisto. Integrar-se abdicando da sua própria cultura?

Sempre que o branco pode, integra o índio isoladamente ou em grupos, nos seus esquemas de atividade económico-cultural. Quando não pode, extermina-o. E na sociedade colonial ainda é difícil conceber separação clara entre econômico e cultural. É nas artes e ofícios que essa integração vai se viabilizar melhor, devido à suzerania da dimensão estética, pretexto mágico de integração. Daí a forte presença de índios na tecnologia musical (fabricação de instrumentos, cópia de música, execução musical e cantoria e, depois, na própria composição).

Esse confinamento também pode ser visto como um pacto de ocupaçăo dos espaços. Qualquer imposição, aí, funciona mais pelo 
aspecto negativo: a proibição de romper o confinamento, de transgredir os espaços. A transgressão sincrética (no caso, estética) é o primeiro passo para a realização da transgressão étnica, ou seja, pela integração, contra a segregação. A transgressão estética do confinamento é um prenúncio de integração e libertação; e isso parece que Mayer Serra não viu. É o sincretismo, ou seja, a manipulação tanto quanto possível livre das formas e configurações, que permitirá a construção gradual de uma cultura alternativa, substância, por sua vez, de uma sociedade mais democrática.

\section{NOTAS}

1) Mayer Serra prefere, como vimos, a expressão "musicologia comparada".

2) Geronimo de Mendicta. História Eclesiástica Indiana, 1596.

Régis Duprat é Professor Titular do Departamento de Expressão e Comunicação do Instituto de Artes da UNESP. 